\title{
Discourse implicature, Quintilian and the Lucidity Principle: rhetorical phenomena in pragmatics
}

\author{
Michael Burke \\ University College Roosevelt, Utrecht University
}

\begin{abstract}
At a meta-level this article seeks to reduce the perceived gap that exists between classical rhetoric on the one hand and linguistics on the other. The linguistic focus here will be on pragmatics and discourse phenomena. In this article, the main tenets of classical rhetoric will first be set out. Thereafter, some examples of productive crossover work from both sides that has sought to unify rhetoric and pragmatics will be discussed. Next, a number of suggestions will be put forward as to why there has been so little cooperation. These will highlight aspects of scope and audience. Finally, some solutions will be offered as to how those perceived stumbling blocks might be eliminated. In this discussion, there will be a particular focus on the pragmatic notion of implicature from the perspective of Grice, the neo-Griceans and also the Roman rhetorician Quintilian. In the case of the latter, his ideas on the importance of lucidity in productive discourse situations will be explored and recast within a light of modern pragmatic theory.
\end{abstract}

Key words:

rhetoric, pragmatics, implicature, Quintilian, lucidity

\section{Introduction}

Is there a role for classical rhetoric in modern linguistic studies and, in particular, in the field of pragmatics? More specifically, can pragmatics benefit from "borrowing" from rhetoric? This is the underlying question that will be addressed in this article.

By taking a concept, in this case implicature, and exploring it from a Gricean, a neo-Gricean and a classical rhetorical perspective, a case will be made that there is indeed much for discourse linguistics to (re)discover in the writings of the ancient rhetoricians and that a combined approach may, in certain cases, enrich the field of pragmatics. This then will be the main argument. However, a consideration of the challenges and the stumbling blocks of such a proposed consolidation will also be considered. The paper will begin with a necessary extended overview of the chief theoretical precepts and principles of classical rhetoric in order to assist the modern reader in positioning his/her knowledge of pragmatics and discourse studies within that familiar yet ancient art.

\section{The main tenets of classical rhetoric} Rhetoric, a branch of linguistics concerning speech quality, writing style and persuasive discourse, is not a simple sub-discipline to define. Rhetoric scholar Peter Dixon, paraphrasing the poet T. S. Eliot, noted how it is "notoriously slippery and imprecise", akin to asking a man to reassemble a freshly dissected jellyfish (Dixon, 1971, p.1). This complexity is not a recent phenomenon. It was also the case back in antiquity. Four very different views of rhetoric are offered by Plato, Aristotle, 
Cicero and Quintilian. Plato (in)famously viewed it from a theoretical perspective as a discursive art that enchanted and deceived the soul. Aristotle was much more pragmatic and considered rhetoric in more methodological terms, stating that it is the faculty of discovering "all the available means of persuasion". Cicero took more of a structural approach and said that rhetoric is an art consisting of five parts or canons. These are (1) invention: the generating or discovering of linguistic material to be used later; (2) disposition: the ordering of selected parts of that material for the best persuasive effect; (3) stylization: giving attention to (i) the clarity of grammar, (ii) the appropriateness of discourse, and (iii) the persuasive nature of style figures, namely schemes and tropes; (4) memorization: the cognitive acquisition of structured techniques for remembering ordered materials/arguments; and (5) delivery: the oral delivery of language with a focus on pitch, duration, voice, etc. and paralinguistic aspects such as bodily movement, stance, gestures and facial expression. Finally, a fourth rhetoric expert from antiquity, Quintilian, about whose theories of discourse interaction we will learn more later, brought a pragmaticethical dimension to rhetoric, saying that rhetoric is the art of speaking well and in particular "the good man speaking well".

Since antiquity, views on the art of persuasive discourse have been equally divided. Francis Bacon claimed that "the duty and office of rhetoric is to apply reason to imagination for the better moving of the will". In a much more negative light, John Locke referred to rhetoric as "that powerful instrument of error and deceit", while I. A. Richards said that rhetoric is "the study of misunderstandings and their remedies". Modern scholars of communication have been more consistent on the topic. Their view can be broadly summed up in the words of contemporary rhetoric scholar Andrea Lunsford, who says that rhetoric is the art, practice and study of human communication (see Eidenmuller, 2008).

The five canons of rhetoric that were set out by Cicero are at the heart of classical rhetoric. Invention, the first of the canons, has two main parts: (1) heuristics, for generating lots of plausibly relevant material (arguments and examples), and (2) more focused intrinsic and extrinsic arguments. Two often-used heuristics are Aristotle's common topics and the later Roman method of stasis theory. The first of these, the common topics, provided three main prompts that concerned conjecture (or fact), degree and possibility. This list of topics was expanded on by rhetoric scholars Corbett and Connors in their work Classical Rhetoric for the Modern Student, who set out five distinct categories with a number of subcategories as can be seen in the TTable 1 .

\begin{tabular}{|c|c|}
\hline 1. Definition & $\begin{array}{l}\text { a. Genus/Division/Species } \\
\text { b. Etymology } \\
\text { c. Description } \\
\text { d. Definition } \\
\text { e. Example } \\
\text { f. Synonyms }\end{array}$ \\
\hline 2. Comparison & $\begin{array}{l}\text { a. Similarity } \\
\text { b. Difference } \\
\text { c. Degree }\end{array}$ \\
\hline 3. Circumstance & $\begin{array}{l}\text { a. Cause and effect } \\
\text { b. Timing }\end{array}$ \\
\hline 4. Relationship & $\begin{array}{l}\text { a. Contraries } \\
\text { b. Exclusion }\end{array}$ \\
\hline 5. Testimony & $\begin{array}{l}\text { a. Statistics } \\
\text { b. Maxims } \\
\text { c. Laws } \\
\text { d. Precedents } \\
\text { e. Personal example } \\
\text { f. Historical example } \\
\text { g. Authoritative quotes }\end{array}$ \\
\hline
\end{tabular}

Table 1: Corbett $\&$ Connors's expanded list of topics of invention $(1999, p .87)$ 
Aristotle also set out three "special" topics that pertained to the three main domains of persuasive discourse. These were: deliberative oratory, i.e. the field of political rhetoric; forensic oratory, i.e. the field of judicial rhetoric; and epideictic oratory (also known as ceremonial or display oratory), which was used either to praise or castigate an individual or institution. The special topics are also known as the three "genres" of rhetoric. They all have a different emphasis. Deliberative oratory focuses on an event in the future, what is good or beneficial for the people or for a state/country. In such political modes of persuasive discourse, speakers urge and exhort people to act or think differently about a specific future matter. Forensic oratory focuses on events in the past, i.e. who did what to whom and when, where and why. In such judicial modes of persuasive discourse, speakers point out what is just or unjust and they accuse or defend in relation to a specific past event. Epideictic oratory focuses on events primarily in the present (but also draws on the past and projects into the future). The key themes are honour or dishonour, and this is expanded on by highlighting episodes of virtue, e.g. wisdom, prudence and generosity, or vice, e.g. stupidity, impetuousness and frugality, regarding a particular individual or institution.

A second main basic heuristic for generating material is "stasis theory" which builds on Aristotle's common topics with arguably more depth. It addresses the four questions of fact, definition, quality and policy, using question prompts. Questions of fact might include: Did something happen? If so, what are its causes? Is there a problem? Can it be changed? Questions of definition could involve: What is the nature of the problem? To what larger class of thing does it belong? What are its parts and how do they relate? Questions of quality might include: Is it a good or a bad thing (and for whom)? Is it serious or trivial (and for whom)? Who does it affect? What happens if we do nothing? Finally, questions of policy could involve: Should action be taken? If so, what should be done, and why? Producing written answers to these question prompts will provide a speaker with material with which he/she can then proceed to select and order for delivery.

In addition to basic heuristics that prompt the generation of text, there is also the notion of the Aristotelian intrinsic and extrinsic proofs or appeals, which also belong to the first canon of rhetoric. The three intrinsic proofs are logos, ethos and pathos. These are arguments that have to be developed and fashioned. The extrinsic proofs, by contrast, are ones that are already out there in the world. You only need to know where to look. In Aristotle's day, extrinsic proofs were things like oaths, contracts, laws, precedents, etc. These days they are things like data, facts, testimony and statistics. The most interesting by far, however, are not the extrinsic proofs but the intrinsic ones.

Logos, the so-called rational persuasive method, employs enthymemes and examples. Enthymemes are deductive in their reasoning force, moving from general to particular, unlike examples which are inductive, leading outwards, from particular to general. Enthymemes are the rhetoric equivalent of the syllogism in logic. Whereas in logic the syllogism must show internal validity to meet truth conditions in the relationship between the three elements of an argument - the major premise, the minor premise and the conclusion - in rhetoric the enthymeme is much "looser". In fact, a part of the argument is deliberately omitted, often the major premise. This is habitually a kind of maxim-like commonplace, a bit of ideology that circulates within a particular society. The skill inherent in the omitted part of the argument is that a willing audience fills it in for the speaker, either verbally or mentally, and in doing so convinces him/herself by reinforcing his/her existing beliefs. The example, the inductive aspect of logos, is the equivalent of induction in scientific reasoning. In scientific inductive reasoning, there need to be many examples that are randomly selected in order for the inductive leap to be narrowed to increase probability. In rhetorical induction, however, the persuasive force is not in the quantity of examples but in their quality. One need have only three or four examples, but if they are strong and vivid, then they can win the day in a persuasive discourse exchange or a persuasive speech when delivered optimally. Examples can be 
historical or fictional, but they can also be analogies, whereby two hypothetical situations are equated, or signs, both the fallible kind and the infallible kind. Logos therefore is an appeal to reason. Its logical antithesis, pathos, is an appeal to emotion.

Pathos is emotional persuasion. The notion of audience is important to the success of pathos, as is the strategic ordering of where it should appear in a discourse and why. One position that most theorists and practitioners of the past have agreed on is at the end of the speech. In a sense, the coda position in rhetorical discourse is not merely for summarization but also for seduction. Structural patterns and mechanisms are usually those that help to facilitate the production of pathetic proofs. These are usually style figures. Probably the most common style figure employed in pathetic proofs is enargeia, a vivid description of a scene that is graphic in nature and, in the words of Aristotle, constitutes a "bringing before the eyes" of the object or event described. Other prominent figures that are employed purposely to elicit emotional responses include: aposiopesis, a breaking off suddenly in the middle of saying something to portray being overcome by emotion; epimone, the persistent repetition of the same plea often using the same or similar words; and apostrophe, a moving away from addressing the audience directly to theatrically addressing an absent other.

The third and final intrinsic proof is ethos, a character-based appeal. It is often divided into two related parts: first, the reputation of the speaker who is about to address an audience; and second, what that speaker actually does and says in and during his/her speech, as well as the manner in which it is done and said. These two aspects of the ethical appeal are sometimes referred to as "situated" and "invented" ethos (Crowley and Hawhee, 2012). Aristotle referred to ethos as the "hidden persuader" because it was not as visible as logos or pathos. He also thought that a speaker must be knowledgeable and benevolent, or rather be seen or understood to be knowledgeable and benevolent. Cicero expanded on this. He thought that the best place for ethical appeals is in the introduction or exordium of a discourse. The speaker should show good will, and it should be clear that he/she is both attentive and receptive.

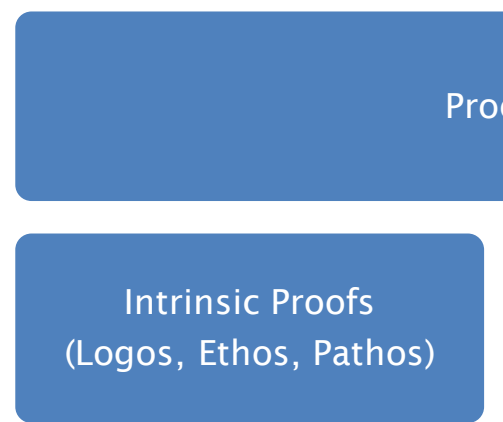

\section{Figure 1: Invention: The first canon of rhetoric}

The ordering of a speech is a matter for the second canon of rhetoric: disposition. Once masses of linguistic material have been generated through the heuristics and external and internal proofs of invention, these then have to be selected and ordered. If done properly, much of what has been generated will go unused.
Different rhetorical theorists in the ancient world had differing views. Aristotle thought that persuasive discourse only had two main parts: you stated the case and then you set about trying to prove it. A more sophisticated model was the sixpart system of a persuasive discourse set out by the unknown author of the 
Rhetorica ad Herennium written around $80 \mathrm{BC}$ and originally, and erroneously, ascribed to Cicero. Each persuasive discourse model has different sections or phases.

The first of these is the exordium, or introduction, where the case/argument is stated. It is also here that according to Cicero a speaker must deploy ethical appeals. This all depends on the audience, which might be mainly accepting, hostile or indifferent, and, to be more specific, on the speaker's assessment of the audience. Cicero identified five broad types of audience (de Inventione I xv, p.19-21). The first type of audience likes you because of your standing in the community (i.e. the first part of ethos) and likes the issue you are about to speak on. In cases of such accepting audiences, Cicero advocated skipping the introduction altogether and proceeding to the arguments in the main part of the speech. He then placed three types of audience in the middle of his spectrum, which he called "mean", "ambiguous" and "obscure". A mean audience finds the speaker and/or issue at hand uninteresting or unimportant. An ambiguous audience is unsure about the issue. An obscure audience finds the issue at hand too difficult to understand either because it is too complex, they are too uninformed about it, or they do not possess the cognitive ability to follow the argument. In all three of these cases Cicero gives two pieces of advice: (a) use direct and plain language, and (b) secure goodwill by deploying linguistic strategies that make the audience well-disposed, receptive and attentive. The fifth and final type of Ciceronian audience is classified as "difficult". This group either dislikes you as a person (i.e. your situated ethos), the topic you are about to speak on, or both. This requires some extra work as a speaker. Cicero referred to this particular kind of textual situation not as an introduction, but as an "insinuation", whereby through linguistic acts of indirection an idea might be discreetly lodged in a hearer's mind. Cicero advised three steps to remove the sting, as it were, of an audience's hostility. First, admit that there is a difference of opinion between you and your audience, then if the issue under discussion is unsavoury to them admit this too and promise to show how your position is defensible. Lastly, if you notice that your audience is generally tired or just weary of having to listen to the same issue over and over, then promise to be brief.

The second part of a persuasive text as set out in the Rhetorica ad Herennium was known as the narrative (narratio). This is the statement of facts or background information, where the scene is set. Here the focus might be on a definition or on values or on describing what must be done. In all cases, speakers are encouraged to be concise, clear and brief. To aid clarity and allow a speaker to follow it, a narrative should have some logic to it, i.e. it must be chronological (backwards or forwards) or proceed from particular to general or from general to particular. The third part is known as "division" (divisio). Also known as the "partition", it is the shortest of all the sections but important for mnemonic reasons with regard to the minds of the audience members. Here, the speaker briefly states the arguments that are to come.

Section four deals with the arguments in favour (confirmatio) and section five with the counter arguments (refutatio). In these sections, the materials and arguments that have been generated by the heuristics in the first canon will now be deployed at length. Aristotle advised that the stronger arguments be placed at the beginning and at the end and that weaker ones be positioned in the middle. Counter arguments are important for your ethos: to show that you are a wellbalanced and fair-minded speaker. These should be fewer in number than your own arguments and be dealt with more briefly.

The sixth and final section is the peroration or conclusion. Cicero said that a peroration should do three things: summarize briefly and deploy both ethical and emotional appeals. Emotional appeals generally seek to cast your opponents, i.e. those who disagree with you, in a negative light by exciting indignation in an audience. For example, one might demonstrate that an opponent's opinion is a threat to a community value or that an opponent's opinion is ignorant of the facts. Ethical appeals in the peroration generally seek to arouse pity or sympathy for yourself or for your case. 


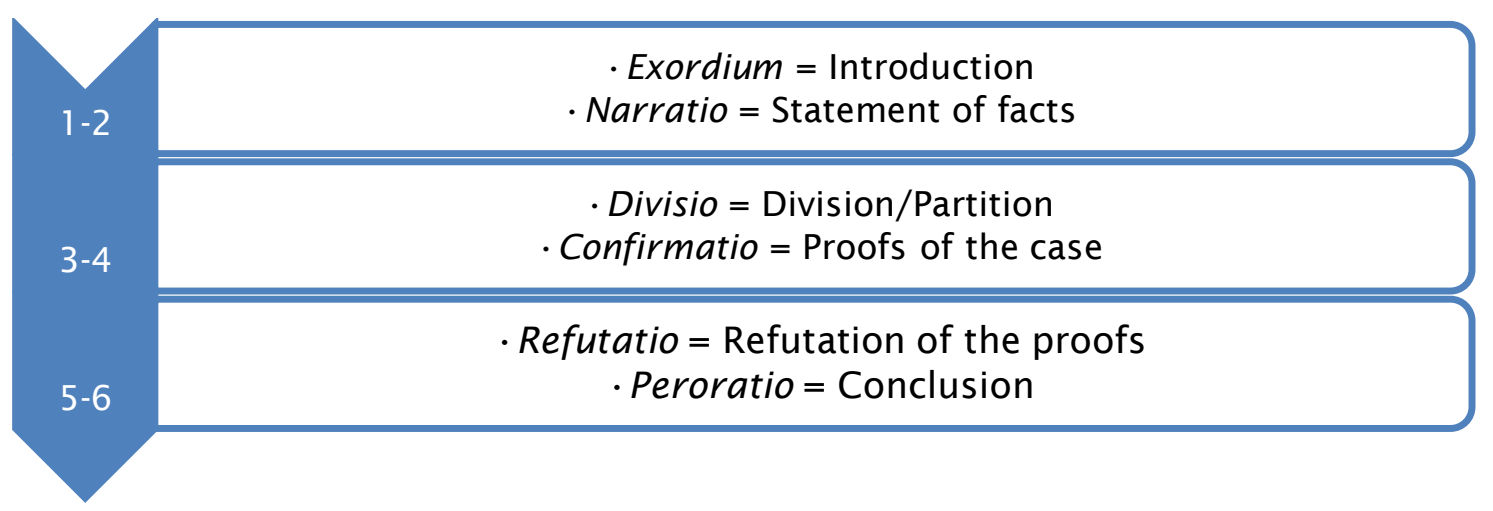

\section{Figure 2: The six-part structure of a persuasive text as described in the Rhetorica ad Herennium}

The third canon of rhetoric concerns style. Cicero said that there are three types of style: plain style, middle style and high or grand style. Each of these is meant to be deployed in specific rhetorical discourse situations. Plain style is for teaching, middle style for pleasing and high/grand style for moving. Plain style seeks to teach or convince using logos, middle style seeks to sway or persuade using a recognizable discourse, and employing ethos and the grand style seeks to move an audience's feelings with the goal of spurring them on to action with pathos. The plain style uses familiar and precise diction; the speaking rhythm should resemble natural speech; and the syntax structure of the text should be simple. Plain style also employs very few or no style figures. The middle style employs a mix of familiar and less familiar diction; rhythms might sometimes deviate from the natural speaking norm; and the sentence structure can vary between simple and complex. A moderate number of style figures, especially tropes, may be employed. In short, it should be a mix of the easy-going and the elegant. Lastly, the high or grand style, unlike the previous two, employs many style figures (especially schemes). Lexis and syntax are ornate and complex and rhythms are dramatic, unlike natural speech. Unlike plain style and middle style, the grand version can only be sustained for a short period.

A persuasive speech has to meet four criteria: it has to employ good grammar; the diction has to be clear; the message has to be appropriate for a given audience in a given situation; and lastly a speaker has to deploy ornaments in the form of style figures, i.e. schemes and tropes, which are bits of language that depart from a norm and in doing so draw the attention of listeners and readers alike. Schemes deviate at the syntactic level while tropes deviate semantically. Examples of schemes include anaphora (the repetition of the same words at the start of successive sentences or clauses); epiphora (the repetition of the same words at the end of successive sentences or clauses); and anadiplosis (the repetition of the final word or phrase from the previous line or clause or sentence at the beginning of the next. Examples of tropes are hyperbole (an exaggeration); oxymoron (a compacted paradox whereby two ordinarily opposing terms are placed side by side); and metonymy (reference to something or someone by naming one of its features). Figures are also sometimes categorized as figures of speech and figures of thought, although the demarcation line between these is not always clear. The Rhetorica ad Herennium makes a further division. It sets out four fundamental operations or categories of change that govern the formation of all figures of speech. These are: (i) addition (adiectio), also called repetition, expansion or superabundance; (ii) omission (detractio) also called subtraction, abridgement or lack; (iii) transposition (transmutatio) also called transferring; and (iv) permutation (immutatio) also called switching, interchanging, substituting or transmutation. 


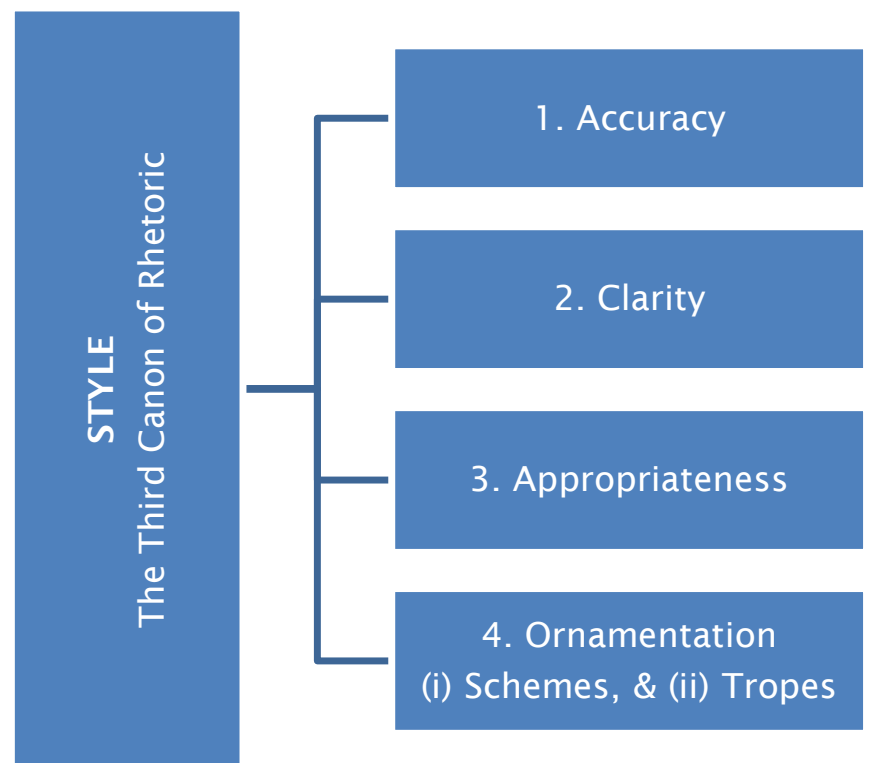

\section{Figure 3: The four aspects of the third canon of rhetoric (style)}

The fourth canon of rhetoric is memory or memoria. The essence of this category is the nature of an artificial memory rather than a natural memory. A speaker has to train his/her memory to remember arguments in a particular order. This is important as speaking extemporaneously, or off-the-cuff as it were, appears more persuasive to the beholder/listener than a speech being read aloud. A number of systems were employed by the ancient rhetoricians. One of these was devised by Aristotle in his work on the Topics. In its essence it concerns having a good stock of definitions and premises. First, one has to remember major commonplaces that circulate in a given community for use in arguments. Second, one has to group these into categories and give each a number. Next, one has to invent a term for the category and choose a keyword from each commonplace/premise. Lastly, one has to organize the commonplaces in each category either numerically or alphabetically.

A second mnemonic strategy was said to have been developed by the Sophists. First a person has to focus on what he/she wishes to remember. Next, one has to repeat the thing to be remembered many times. Finally, one has to associate the thing to be remembered with vivid and unusual images. For example, if one has to remember a name like Peter Smith one could imagine a "petrified" "blacksmith", whereby you use such things as etymology and word extension to create a vivid and unusual image that can be directly related back to the original name "Peter Smith". Similarly, etymology can be used to remember objects, things and professions.

A third system for remembering arguments and materials, and probably the most familiar today, is the so-called method of loci, also known as the memory palace, described by Cicero in his telling of the tale of the Greek poet Simonides and also set out in detail in the $1^{\text {st }}$ century $\mathrm{BC}$ rhetorical handbook Rhetorica ad Herennium. What the memory palace model entails is the systematic ordering of very familiar places, such as your current home, your childhood home or your current place of work, with strikingly vivid, memorable features. Let us imagine that a speaker wants to argue for the use of more solar energy in his country, and the three arguments he wishes to make and deliver, in this order, concern economic, social and environmental aspects. He may start by imagining walking into his childhood home. As he enters the house, immediately to his left is a door leading to a dining room. The next door on the left leads to a living room/lounge. The next door, which happens to be directly in front of him, leads to the kitchen. He now takes his first (economic) argument and creates a vivid image in the first room. This could, for example, be a large golden coin with hands and legs, jumping up and down on the dining table. Next, for his social argument he could imagine a group of happy suns socializing and having a 
cocktail party in the lounge. Lastly, for his environmental argument in the kitchen the tap could have been left on, and as he opens the door he sees a large pair of brightly coloured red wellington boots slowly disappearing under the rising water level.

The fifth and final canon involves delivery, which has both linguistic and para-linguistic elements. At the core of this canon is the question of how to obtain the optimum delivery in a given setting. The ancients prescribed a number of writing exercises that might help accomplish this, including copying, imitating and thereafter analysing the speeches of others. Another core aspect was practising one's delivery aloud until it was perfected. The main linguistic aspect of delivery is voice quality, while the main paralinguistic aspect is physical movement. Voice quality is a matter of pitch, volume, intensity, emphasis, etc. An important aspect of voice quality is pausing rhetorically and strategically. Physical movement is a matter of hand gestures, facial expressions (related mainly to the eyes and mouth) and bodily movement, incorporating posture, stance and movement.

These then are the five canons: invention, arrangement, stylization, memorization and delivery, and they are all held together and determined by the glue of what the ancients called "Kairos". Kairos is about spatial time, as opposed to our more default sense of linear time. A window on time opens up and a speaker has to first acknowledge it and second to step into it. He has to "seize the moment" and "strike while the iron is hot". Kairos concerns a whole host of related contextual factors that can determine the meaning and the effectiveness of a persuasive utterance. For example, it is about the place or location of a persuasive utterance, the time when it takes place, the reputation of the speaker in the context of a specific audience, the relationship between the audience and the speaker and the relationship between the audience and the issue or topic that the speaker has chosen to deliberate on. All these things, and more, go into what is sometimes termed the rhetorical situation. In short, meaning is not determined by the actual language/words alone but by who says what to whom, when, where, how and why.

This then completes a synopsized account of the main aspects of classical rhetoric. We will now proceed to survey the work that has been realized in the area of unifying rhetoric and pragmatics. Thereafter, we will examine what might have restricted this process. Finally, plausible resolutions will be offered as to how those perceived stumbling blocks might be addressed.

2. Pragmatics and classical rhetoric: realizations, restrictions and resolutions While going through the above synopsis on the main precepts and principles of classical rhetoric, a number of possible pragmatic-rhetorical exchanges or connections may have been identified by readers. Broadly speaking, pragmatic issues that may very well have come to mind include conversational/discourse implicature, the co-operative principle, conversation analysis, relevance theory and politeness theory. It is useful to reflect on what the first of these actually entails, as it will play a significant role in this paper. At the core of conversational implicature - or what is being referred to here as "discourse implicature" - is the realization that it is not the conventional meaning of the words that matters in optimal discourse situations, but rather the implicit principles of how people in given communities and in given situations use language. In short, knowing "what is said" is not enough; one needs to know "how that which is said is actually used in communicative practice". An example is below:

A. Will Billy be at the match this afternoon?

B. His car has broken down and the train workers are on strike again

Here, person $B$ is not commenting on the state of a particular automobile or on industrial action that is being taken by rail workers, but rather that a certain person will probably not be present at a particular football match later that day. Often, the hearer must also take into account the factors that a rhetorical situation might throw up, just as we saw earlier in our discussion on kairos. In other words, the 
context of utterance can be crucial in meaning making.

\subsection{Realizations}

It is not unreasonable to state that in truth not an awful lot of work has been done in pragmatics that has its roots in classical rhetoric. There have, however, been some thought-provoking studies conducted, three of which will be briefly highlighted below. One particular area that has rich potential crossover is conversational implicature from pragmatics and the enthymeme from logos, the first of the intrinsic proofs located in "invention", the first canon of rhetoric. For example, in an article on the structure of conversational argument, Jackson and Jacobs (1980) explore the pragmatic bases for the enthymeme. Focusing on adjacency pairs and their general properties, they make a case for the prevalence of persuasive enthymemes in everyday conversational turns. This theme of implicature and the enthymeme has been explored more recently and in much great depth by Nemesi (2013) in an engaging article that appeared in the Journal of Pragmatics. Nemesi starts by posing the general question as to whether pragmatics should stick to its own concepts or whether it should incorporate key ideas and notions from classical rhetoric. He never quite answers this in a straight-forward fashion, but judging by the nature of his arguments and cases, his choice is for an inclusive and unifying model. His focus is on the enthymeme, although he also incorporates tropes and figures of thought from the third canon of rhetoric that deals with style in persuasive discourse (elocutio). With regard to the enthymeme, he observes that its vagueness, along with the equal nebulousness of implicature, does not make it easy to assess how similar they are. He does, however, see them as complementary in the sense that in implicatures it is the conclusion of an argument that remains unexpressed, while in enthymemes it is one or more of the premises that gets omitted. The purposively sampled instances he provides do lend support to this claim. However, a much broader corpus of examples, preferably randomized, might be necessary to make this inductive argument more durable. On the matter of style figures, he observes that studies on tropes, such as those that deal with metaphor or metonymy, are common fare in pragmatics. Studies on figures of thought, however, are not and it is here where Nemesi explores which figures of thought might convey conversational implicature and why. Such "pure" studies in this crossover area of pragmatics and rhetoric have also been complemented by more "applied" ones. Keller (2010), for example, combines pragmatics and classical rhetoric to form an expanded framework for the linguistic analysis of Shakespeare's Othello. In combining politeness theory and relevance theory from pragmatics with style figures from rhetoric, he is able to achieve a far more detailed analysis of Shakespeare's dramatic language than would otherwise have been possible by just using either in isolation. This combination, he claims, opens up new approaches that allow us to access the very substance of Shakespeare's dramatic dialogues.

Such opinions are not just one-way traffic - that is, from pragmatics to rhetoric. Although a vast majority of modern scholars of classical rhetoric leave the linguistic resources of pragmatics untapped (perhaps because rhetoric scholars come from a variety of, often non-linguistic, disciplinary backgrounds, including literary studies, pedagogy, philosophy, law and political sciences), there are some interesting outliers. For example, in an article by Dascal and Gross (1999) aptly entitled "The marriage of pragmatics and rhetoric" the authors acknowledge the great debt that is owed to the pragmatics and logic scholar Grice when it comes to studies on the interaction between speakers and hearers. Comparing Aristotelian rhetoric and Gricean pragmatics, they highlight how the two might benefit each other. Rhetoric can benefit from pragmatics by realizing that its practices offer coherent theories of cognitive discourse studies. Pragmatics can benefit from classical rhetoric by going beyond the study of conversational exchanges to include the study of dialogues that are not merely logically informative but rhetorically persuasive. How much Grice himself was formed or influenced by classical rhetoric as a young man is uncertain. In a thorough linguistic autobiography on Grice by Chapman 
(2009), no mention is made of classical rhetoric.

An exception to the idea that pragmaticians do not do rhetorical theory is Geoff Leech. In his work Principles of Pragmatics (1983), Leech develops a kind of rhetorical model of communication whereby he distinguishes between textual rhetoric and interpersonal rhetoric. The former is close to the Gricean Cooperative Principle and is concerned with being informative in particular on matters of quality, quantity, relation and manner. The latter is what Leech terms the Politeness Principle and is concerned with relational and interactive linguistic skills. Leech notes how the two (the textual and the interpersonal) must work together in order to perform their functions effectively in everyday communication. A central issue that Leech is concerned with is "why is it that people are often so purposefully indirect in conveying what they mean?" This, of course, is always culturally constrained; for example, some cultures are very direct, others extremely indirect. Leech sets out six maxims in his Politeness Principle, each of which have two sub-maxims, where the former tends to carry more weight that the latter. These are listed in Figure 4.

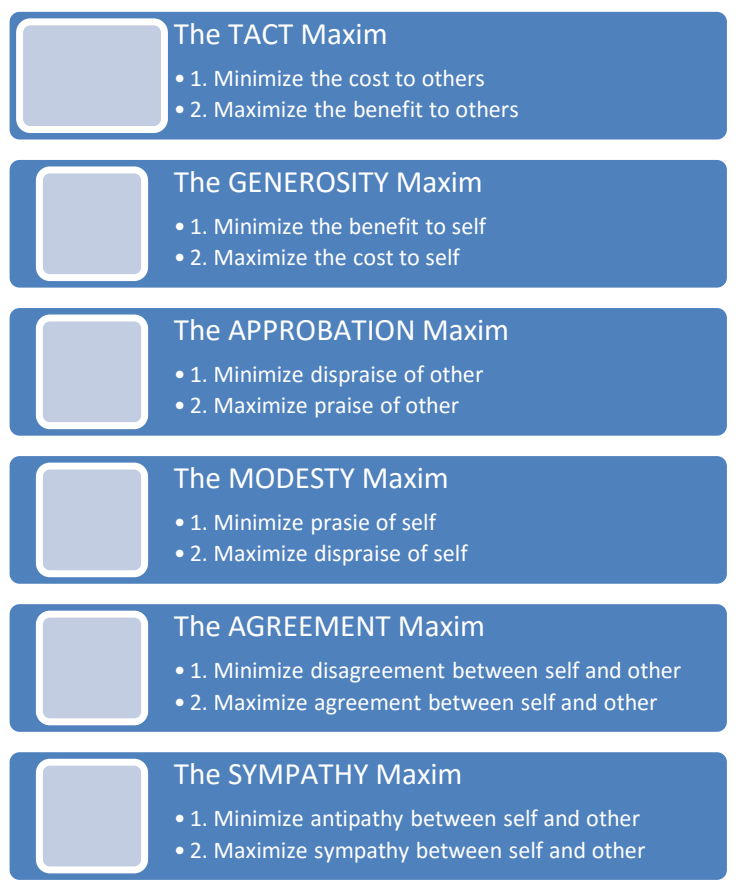

\section{Figure 4: Leech's Politeness Principle (1983)}

Although not immediately rhetorical in the classical sense, as described earlier in this paper, what Leech's model draws on as a persuasive tool is "character", i.e. ethos, an Aristotelian intrinsic proof, located in the first canon of rhetoric. In particular, it is reminiscent of Cicero's communicative strategies with regard to drawing on ethical appeals during an exordium/introduction, such as creating goodwill in your interlocutors or hearers and making a person or audience attentive and receptive. Leech's Politeness Principle also echoes aspects of Kenneth Burke's famous rhetorical theory that is set out in his Rhetoric of Motives (1950). In this work the concept of "identification" is central, in the sense that in order to persuade a person one must first identify with him/her. Leech's Politeness Principle certainly goes some way towards laying the groundwork for such a Burkean act of persuasive/rhetorical identification to take place.

\subsection{Restrictions}

The examples in the previous section, although engaging and convincing, are exceptions. The question remains that given the clear potential for mutual enrichment, "why has there been so little cooperation between pragmatics and classical rhetoric?" For example, in some of the most quoted handbooks and textbooks on classical rhetoric, there is very little or no mention of pragmatics or any discourse or pragmatic-related theories (Brummett, 2006; Conley, 1990; Corbett and Connors, 1999; Crowley and Hawhee, 2012; Dixon, 1971; Herrick, 2005; Kennedy, 1994; 1998; Olmsted, 2006; Pernot, 2005; Ramage, 2006; Richards, 2008). Correspondingly, modern handbooks and textbooks on different aspects of pragmatics also say little or nothing about classical rhetoric (Blakemore, 1992; Brown and Levinson, 1987; Chapman, 2011; Clark, 2013; Grundy, 2008). So why has there been so little cooperation? To my mind there are a number of related, perceived contradictions between the two that for some scholars just seem unbridgeable. These are: (i) the public vs. private argument; (ii) the speeches vs. conversations argument; and (iii) the single audience vs. group audience argument. 
Rhetoric is often seen as primarily a public discourse act. A person speaks in a civic setting, addressing an audience of hearers. Conversely, pragmatics focuses on private acts of discourse exchange. This argument is expanded in the second division listed above, whereby rhetoric concerns discourse acts described as speeches, orations and monologues, whereas pragmatics focuses on conversations, talk and dialogues. The third division highlights the difference in audience: rhetorical speakers address the many (audiences, listeners and hearers), whereas speakers in a pragmatic setting address a fellow interlocutor or debater. There is of course some truth in these assertions. However, they all make the mistake of thinking exclusively in classifications, whereas discourse situations are almost always a matter of clines not categories. For example, conversations can be public, orations can have an inter-discursive character, conversations can be persuasive rather than merely informative and an oration can be delivered by one person to another, i.e. a multi-person audience is not a necessary condition. In short, the perceived distance between rhetoric and pragmatics is decidedly more imaginary than it is real.

\subsection{Resolutions}

An appreciation of just how close pragmatics and rhetoric are can be gleaned by considering a cornerstone of pragmatic theory: the Gricean maxims of communication (1975) and also by examining the work of the so-called neo-Griceans, in particular Horn, Levinson and Sperber \& Wilson (although Sperber and Wilson's relevance work is more accurately termed "post"-Gricean rather than "neo"Gricean). Grice's famous maxims of communication are: (i) quality (be truthful); (ii) quantity (be informative); (iii) relation (be pertinent); and (iv) manner (be clear). The model concerns the successful traits of mutual communication. The maxims take up complementary roles. Quality is about not saying that which is untrue or for which you have no evidence, so avoid exaggeration and fantastical descriptions. Quantity concerns not giving too much or too little information about a matter, so evading repetition and redundancy. Relation is about not digressing from the issue at hand. Finally, manner is concerned with being brief, clear, orderly and generally avoiding ambiguity, so not being purposely vague or oblique. The model has been critiqued. For example, Clyne (1996) found it to be too Anglo-centric, claiming that it takes no or little account of intercultural communication. This led him to revise and expand it. Different kinds of further revisions have also been conducted mainly by logicians known collectively as the "neo-Griceans". Unlike Clyne's intercultural development of the maxims, these are all reductionist in nature.

Horn (1984), for example, proposes two rather than four conversational implicatures, which he calls the Q (quantity) and R (relation) Principles. His reasoning behind this reduction is that there are, to his mind, several redundancies and repetitions in the theory. Horn's principles include three of Grice's maxims: those of quantity, relation and manner. Quality is excluded as truthfulness should be a given anyway. The Q-Principle combines part of the first maxim, quantity, with part of the fourth maxim, manner. These are "make sure that your contribution is as informative as is required", i.e. say as much as you can, and "avoid both obscurity and ambiguity". The Q-Principle is said to be "hearer orientated" in that it addresses his/her needs in getting as much information as possible. The R-Principle covers Grice's maxim of relation (be pertinent/relevant), together with the idea that "one should not say more than what is required" from the quantity maxim, and also "be brief" and "be orderly" from the manner maxim. The R-Principle is said to be "speaker orientated" in that it addresses his/her needs in ensuring that he/she doesn't need to go to the effort of saying more than is minimally required. Horn's key concern in his reductionist pragmatic theory is communicative efficiency. In this sense, it closely follows Zipf's (1949) principle of least resistance/effort. If one thinks about what Horn is claiming, the Principles appear to be contradicting each other. The advice for speakers appears to be "do as much work as you can but at the same time do as little as you can get away with". What is probably happening though 
is that instead of eliminating each other, they are actually applying necessary mutual constraints, thus eliminating both endless talking on the one hand from the Q-Principle and silence on the other from the R-Principle.

It can be said that what Horn fails to do is to differentiate clearly between those maxims that are concerned with propositional content and those that those that are concerned with the pure form of an utterance (see Chapman, 2011, p.100). This was first noticed by Levinson (2000) who went on to produce his own neoGricean take on conversational implicature. Levinson's pragmatic theory consists of three principles: the QPrinciple, the I-Principle and the $M$ Principle. These pertain to quantity, informativeness and manner. In a similar way to Horn, the maxim of quality is omitted. Also like Horn, there is a speaker and hearer angle. Levinson's $Q$ and I Principles do more or less the same work as Horn's Q and R Principles. Levinson's third principle of manner (the M-Principle) is included to help differentiate between the form of an utterance and its propositional content. In a sense, what Levinson appears to be proposing in expanding the number of principles is that Horn's reduction of Grice's maxims was perhaps a little too enthusiastic. An extra dimension to Levinson's system is that it requires the logical form of an utterance not just to be open to semantics but also to pragmatics. This idea of a "generalized conversational implicature" means that contextual pragmatic knowledge, like, for example, deictic markers such as "here" and "there", are needed to fully understand truth-conditional content. In this sense, Levinson's theory may be reductionist on the surface (going from four to three maxims), but it ends up doing quite a bit more work than Grice's original conversational maxims. We might say that whereas Grice (and indeed Horn) are fundamentally linguistic logicians, Levinson appears to be more of a potential linguistic rhetorician.

A third neo-Gricean (or post-Gricean) approach is that set out by Wilson and Sperber (1981) and expanded on in Sperber and Wilson (1986). It is simply known as "Relevance" and is more of a cognitive rather than a behavioural theory. These researchers began by questioning both the nature of Grice's pragmatic principles and the way in which they function during acts of communication. They pointed out that Grice's maxims are decontextualized, arguing that preutterance, pragmatic inference was needed to fully understand both what is overtly and covertly communicated. They then turned to classical rhetoric (either knowingly or otherwise) and specifically to style figures, in particular to tropes such as irony and metaphor. Grice's theory, they observed, would place something like "irony" in the category of quality. Once there, it would be deemed untruthful and therefore uncooperative. This is clearly a flaw in the Gricean maxims, as linguistic communities use, to a lesser or greater extent, such figurative (rather than literal) units of language on a regular basis without the principles of cooperation being hindered. Sperber and Wilson then, in a reductive turn, concluded that all four maxims can be collapsed into one: the principle of relevance, which induces a hearer to believe that a speaker has done his/her best to be maximally relevant in a specific discourse context.

We can reflect on these discussions on conversational implicature and conclude that it was Grice who started what has turned out to be a fecund and enlightening intellectual discourse on communicative strategies. But did it start with Grice? The simple answer to this is "no, it did not". In fact, such discussions and debates have been going on in Western Europe for more than two thousand years. Let us take a relatively recent example in that history from two thousand years ago. Quintilian wrote his magnum opus The Orator's Education (Institutio Oratoria) in Rome towards the end of the $1^{\text {st }}$ century AD. His writings were based on a life of teaching rhetoric and the rhetorical works and theories of Cicero (written some hundred years earlier) and implicitly the work of the Greek rhetoric scholars who had influenced Cicero: Theophrastus, Aristotle and Isocrates, to name just three. Quintilian's work is set out in twelve books, and the floorplan of the work follows the previously mentioned five canons of rhetoric. By Book 8 Quintilian has reached the third canon, style or elocutio (what the Greeks called phrasis). In section 8.0, which is entitled 
"prooemium" (basically a "preface" or "prelude"), after briefly summarizing the main precepts and principles of the first and second canons of rhetoric, Quintilian now turns to the challenging question of elocution. He says "What I want is care for words... a deep concern for the subject. Most commonly, the best words are bound up with the subject ..." (8.0, pp.20-21). This idea echoes in a way Sperber and Wilson's observation that pre-utterance, pragmatic inference is needed to fully understand both what is explicitly and implicitly communicated. In this same section, Quintilian argues that "the best words are the least far-fetched and resemble those simple words that spring from reality" (8.0. p.23). There are clear parallels here with Grice's maxims of both quality and especially manner, namely "be informative" and "be clear". Quintilian adds the following thought:

Our love of words makes us go round in circles to express what could be said directly, repeat what has been said already, load a thought with many words where one would make it clear and often think it better to drop a hint than to speak it out straight. $(8.0$, p.24)

One could feasibly synopsize this quote with three short statements: "be informative, be relevant, be clear". He also protests about the current trend of borrowing all kinds of style figures, and especially metaphors, from what he refers to as "decadent poets" saying, "And yet Cicero had laid down quite clearly that the greatest fault in public speaking was to distance oneself from ordinary language and our normal instinctive usage" (8.0, p.25). Our words, he asserts, should be correct, lucid and elegant (8.0, p.26).

In section 8.2, Quintilian turns his stylistic interest centrally to the matter of "lucidity", which is also the title of the first part of the section. Lucidity is viewed here as primarily a matter of "propriety", in the sense that we should call "everything by its right name" $(8.2$, p.1). This assertion is not as prescriptive or as rigid as it may first seem. Discussing style figures, for example, he says of metaphor, which he also terms "the greatest ornament of oratory", that it "fits words to things which do not belong to them. Propriety therefore is relative not to the word but to its semantic value, and is to be judged not by the ear but by understanding" (8.2, p.6). What Quintilian is talking about here is not necessarily semantics in its modern sense but pragmatics avant la lettre. Later in this same section Quintilian turns his attention from lucidity to "obscurity", which he describes generally as "words no longer in common use" (8.2, p.12). During this discussion he comments on the flaws of conciseness, and here he reports how "Others, in their zeal for brevity, cut out even essential words from their discourse; as though it was enough that they should themselves know what they mean, they regard other people's concern in the matter as of no importance" (8.2, p.19). He continues "My view, however, is that any expression is faulty which the hearer has to make a mental effort of his own to understand" (8.2, p.20). This can readily be summarized as "make your contribution as informative as is required" from Grice's category of quantity. It is also in line with the speaker's maxim from Levinson's Q-Principle, namely, "do not say less than is required". Quintilian sums this section up by saying "Let us then take as the primary virtue Lucidity, 'proper' words, straightforward order, no longdelayed conclusion, nothing missing and nothing too much. This will lead to language that is acceptable to the learned and plain to the unlearned" $(8.2$, p.22). In line with the neo-Griceans of the late 20th century, I propose to term this Quintilian's L-Principle (for lucidity/lucidum).

If Quintilian were to have been a neoGricean living in the late 20th century, he would not have collapsed the maxims into a single aspect of relation, namely, "relevance", as Sperber and Wilson did. Rather, he would have reduced them to a single aspect of manner: "avoid obscurity". His book therefore would not have been called "Relevance" but "Clarity". 


\begin{tabular}{|l|l|}
\hline $\begin{array}{l}\text { Quintilian } \\
\text { The L-Principle }\end{array}$ & $\begin{array}{l}\text { Grice } \\
\text { The Maxims }\end{array}$ \\
\hline Proper words & Manner [A] - Avoid obscurity. Avoid ambiguity. \\
\hline Straightforward order & Manner [B] - Be brief. Be orderly. \\
\hline Nothing missing & $\begin{array}{l}\text { Quantity [A] - Make your contributions as informative as is } \\
\text { required for the current discourse situation. }\end{array}$ \\
\hline Nothing too much & $\begin{array}{l}\text { Quantity [B] - Do not make your contribution more informative } \\
\text { than is required for the current discourse situation. } \\
\text { Relation - Be relevant. }\end{array}$ \\
\hline
\end{tabular}

\section{Table 2: Quintilian's Lucidity-based Principle and its Gricean maxim equivalents}

It is clear that Quintilian's rhetorical system of lucidity in discourse implicature can be located in Grice's logical maxims of conversational analysis. Quintilian closes his discussion on lucidity in a candid fashion by saying "If we say no less and no more than we ought, and avoid disorder and indistinctness, things will be clear and obvious even to an inattentive audience" (8.2, p.23).

Like the neo-Griceans, Quintilian does not consider Grice's category of "quality" ("Do not say what you believe to be false / Do not say that for which you lack adequate evidence") in his L-based principle. However, we must not jump to hasty conclusions. The one single concept that straddles the entirety of Quintilian's twelve-volume work on the orator's education is the notion of the vir bonus dicendi peritus, "the good man speaking well". In book twelve he returns to the theme, saying "So let the orator whom we are setting up be, as Cato defines him, 'a good man skilled in speaking', but - and Cato put this first, and it is intrinsically more significant and important - let him at all events be a good man" $(12.1$, p.1). Indeed Quintilian goes on further to state that "no one can be an orator unless he is a good man" (12.1, p.3). This arguably more than covers Grice's category of quality, which states one must not say what one believes to be false and one must not say that for which one lacks adequate evidence. In the end, therefore, the quality principle of the good man speaking is both superordinate and intrinsic to the quantity, relation and manner categories of the Lucidity Principle.

Of course there are also places where rhetoric does not appear to sit comfortably alongside Grice's model. For example, the maxim of quality advises against fantastical description. Such phenomena are the persuasive bread and butter of rhetorical pathos. Similarly, quantity prescribes avoiding repetition. However, structured and strategic repetition is part and parcel of a number of rhetorical techniques, including many style figures, especially schemes, which repeat sentences, clauses, phrases and words either at the end or the beginning of successive linguistic units. A final example involves the maxim of manner: the idea of not being purposely oblique. If we were to consider what Cicero prescribes in his insinuation guidelines during exordia for dealing with hostile audiences, we would see that the strategies he proposes in such opening situations are far from straight-forward.

Perhaps then, because we readily accept that Horn, Levinson and Sperber \& Wilson are neo-Griceans, we should also view Grice as a neo-Quintilian or arguably - because Quintilian based most of his work on the theories and frameworks of Cicero - a neo-Ciceronian. Maybe future implicature research should be exploring "the Cicero-Principle". A more detailed study of all the rhetorical theories and frameworks that Cicero devised - and also deployed himself in practice - will shed more light on this suggestion.

\section{Conclusion}

It is hoped that this discussion might reignite an interest in classical rhetoric among scholars of pragmatics, discourse studies and linguists in general (scholars of phonetics, morphology, syntax and semantics). Promising rhetorical areas for further pragmatic and discourse focus are enthymemes, style and style figures. Other areas not yet explored but bursting with potential include: ethos, i.e. the character of the speaker, the study of exordia, i.e. opening moves in discourse exchanges; and kairos, i.e. the rhetorical situation 
surrounding the discourse act. PragmaRhetorico scholarship will surely invigorate both classical rhetorical studies and pragmatics.

To conclude, Grice once wrote "I have stated my maxims [as if the purpose of talk exchanges] were a maximally effective exchange of information; this specification is, of course, too narrow, and the scheme needs to be generalized to allow for such general purposes as influencing or directing the actions of others" (1989, p.28). Such a "generalization" of the model can take place if the relatively micro logical-linguistic world of pragmatics were to open up to the decidedly macro oratorical-linguistic world of rhetoric. As to the question of whether such a mutual and cooperative relationship might help develop our knowledge of how linguistic utterances work in the world - at both an information level and a persuasive level only future research can elucidate.

\section{References}

ARISTOTLE., 1926. The art of rhetoric. Trans. J. H. Freese. Cambridge, MA: Harvard University Press/William Heinemann Ltd.

BLAKEMORE, D., 1992. Understanding utterances: An introduction to pragmatics. Oxford: Blackwell.

BROWN, P. and LEVINSON, S., 1987. Politeness: Some universals in language usage. Cambridge: Cambridge University Press.

BRUMMETT, B., 2006. Rhetoric in popular culture. $2^{\text {nd }}$ ed. London: Sage

BURKE, K., 1950/1 992. A rhetoric of motives. Berkeley: University of California Press.

CICERO., 1949. De inventione (On invention). Trans. H. M. Hubbell. Cambridge, MA: Harvard University Press/William Heinemann Ltd.

[CICERO]., 1981. Rhetorica ad Herennium. Trans. H. Caplan. Cambridge, MA: Harvard University Press/William Heinemann Ltd.

CHAPMAN, S., 2009. Paul Grice: Philosopher and linguist. London: Palgrave Macmillan.

CHAPMAN, S., 2011 . Pragmatics. London: Palgrave, Macmillan.

CLARK, B., 2013. Relevance theory. Cambridge: Cambridge University Press.

CLYNE, M., 1996. Inter-cultural communication at work: Cultural values in discourse. Cambridge: Cambridge University Press.

CONLEY, T. M., 1990. Rhetoric in the European tradition. Chicago: Chicago University Press.

CORBETT, E. P. J. and CONNORS, R. J., 1999. Classical rhetoric for the modern student. $4^{\text {th }}$ ed., Oxford and New York: Oxford University Press.

CROWLEY, S. and HAWHEE, D., 2012. Ancient rhetorics for contemporary students. $5^{\text {th }}$ ed. London: Pearson Education Inc.

DASCAL, M. and GROSS, A. G., 1999. The marriage of pragmatics and rhetoric. Philosophy and Rhetoric, vol. 32, no. 2, pp. 107-130.

DIXON, P., 1971. Rhetoric. London: Methuen and Co Ltd.

EIDENMULLER, M., 2008. Great speeches for better speaking. Columbus, OH: McGraw-Hill Education.

GRICE, P. H., 1975. Logic and conversation. In: P. Cole, J.L. Morgan, eds. Syntax and semantics 3: Speech acts. New York: Academic Press, pp. 41-58.

GRICE, P. H., 1989. Studies in the way of words. Cambridge, MA: Harvard University Press.

GRUNDY, P., 2008. Doing pragmatics. $3^{\text {rd }}$ ed. London: Routledge.

HERRICK, J. A., 2005. The history and theory of rhetoric: An introduction. $3^{\text {rd }}$ ed. London: Pearson Education Inc.

HORN, L. R., 1984. Towards a new taxonomy for pragmatic inference: Q-based and R-based implicature. In: D. Schiffrin ed. Georgetown University Round Table on Languages and Linguistics. Washington, DC: Georgetown University Press, pp. 11-42.

JACKSON, S., and JACOBS, S., 1980. Structure of conversational argument: Pragmatic bases for the enthymeme. Quarterly Journal of Speech, vol. 66, no. 3, pp. 251-265.

KELLER, S. D., 2010. Combining rhetoric and pragmatics to read Othello. English Studies, vol. 91 , no. 4, pp. 398-411.

KENNEDY, G. A., 1994. A new history of classical rhetoric. Princeton, NJ: Princeton University Press.

KENNEDY, G. A., 1998. Comparative rhetoric: A historical and cross-cultural introduction. Oxford and New York: Oxford University Press. 
LEECH, G., 1983. Principles of pragmatics. London: Longman.

LEVINSON, S., 2000. Presumptive meanings: The theory of generalized conversational implicature. Cambridge, MA: MIT Press.

LOCKE, J., 1995. An essay concerning human understanding. London: Prometheus Books.

NEMESI, A. L., 2013. Implicature phenomena in classical rhetoric. Journal of Pragmatics, vol. 50, no. 1 , pp. 129-151.

OLMSTED, W., 2006. Rhetoric: An historical introduction. Oxford: Blackwell Publishing.

PERNOT, L., 2005. Rhetoric in antiquity. Trans W. E. Higgins. Washington D.C.: The Catholic University of America Press.

QUINTILIAN., 1921. Institutio Oratoria. Trans. D. A. Russell. Cambridge, MA: Harvard University Press/William Heinemann Ltd.

RAMAGE, J. D., 2006. Rhetoric: A user's guide. London: Pearson Education Inc.

RICHARDS, I. A., 1965/1936. The philosophy of rhetoric. New York and London: Oxford University Press.

RICHARDS, J., 2008. Rhetoric. London: Routledge.

SPEDDING, J., ELLIS, R. L. and HEATH, D., D., eds. 2011 . The works of Francis Bacon: Vol 3 The philosophical works. Cambridge: Cambridge University Press.

SPERBER, D. and WILSON, D., 1986. Relevance: Communication and cognition. Oxford: Blackwell.

WILSON, D, and SPERBER, D., 1981, On Grice's theory of conversation. In: P. Werth, ed. Conversation and discourse. London: Croom Helm, pp. 155-78.

ZIPF, G. K., 1949. Human behavior and the principle of least effort. Oxford: Addison-Wesley Press.

\section{Author's address and contact details}

Professor Dr. Michael Burke

University College Roosevelt, Utrecht University

Langenoordstraat 1

$4331 \mathrm{CB}$, Middelburg

The Netherlands

E-mail:m.burke@ucr.nl 